\title{
The Effect of Capital Expenditure On Profitability With the Size of Company As The Moderating Variables
}

\author{
Totok Haryanto ${ }^{1}$, Maharani Retnaningrum ${ }^{2}$ \\ \{feb.ump.th@gmail.com ${ }^{1}$, maharani.retna88@gmail.com² \\ Faculty of Business and Economic Universitas Muhammadiyah Purwokerto
}

\begin{abstract}
The purpose of this research is to analyze the impact of capital expenditure (CAPEX) on profitability which is moderated by firm size. The variables used in this study is the capital expenditure (CAPEX), Profitability, and Firm Size which is proxied by Ln (Total Assets). The hypothesis in this study is tested using multiple regression analysis (MRA) to examine the impact of independent variables on the dependent variables and moderation.

The results illustrated that the CAPEX has an influence on profitability which moderated by firm size.
\end{abstract}

Keywords: Capital Expenditure, Profitability, Size of the Company, MRA

\section{Introduction}

The Indonesian telecommunications industry has experienced rapid development. In accordance with the Presidential Regulation Government Work Plan (Perpres RKP) number 79 of 2017 shows that the actual economic growth of 5.3\% in 2016, with projected growth in the range of 5.5-5.9\% for 2017. The information and communication sector notedt the biggest growth compared to other sectors, with actual growth of $10.7 \%$ in 2016 and 2017 projections in the range of $10.5 \%-10.9 \%$. This highest growth was dominated by cellular telecommunications, including Telkomsel, Indosat Ooredoo, and XL Axiata. In the effort to meet market demand, and to maintain or increase its market share, and in an effort to increase profitability, the company faces a number of decisions, one of which is a decision on capital expenditure (investment) through capital expenditure or CAPEX. The company's capital expenditure through the acquisition and use of assets is directed to obtain benefits or cash inflows in more than one operating period (accounting).

In a study conducted by Fitri [6], there was a significant relationship between an increase in capital expenditure (CAPEX) and an increase in company performance. The research was conducted on 118 manufacturing companies in Indonesia. The results of other studies that used a sample of 116 manufacturing companies, showed that there is a relationship where Return on Assets (ROA) is closely related to the level of profit that is proxied by the value of the company [26]. The result of simultaneous testing shows that CAPEX which is moderated by the company's performance which is proxied by Return on Assets (ROA), has a significant influence on the level of profit [19]. The role of company performance can be interpreted as a moderator variable component of CAPEX to profitability. In this study, it was proven that the econometrics model that included the influence of quasi moderation variables of company 
performance and CAPEX on earnings had a large coefficient of determination that was $86.49 \%$ compared to the tested econometrics model that did not include the effect of pseudo moderation variables of company performance and the econometrics model. without moderator variables. This proves the company's performance plays a role in determining the effect of CAPEX on the level of profitability.

With the results of various previous studies, it shows that the variable used is still limited to one indicator of company performance, namely Return on Assets (ROA). In this study, the researcher tries to develop by replacing the moderating variable with the size of the company that is proxied into Ln (Total Assets). So that it will be known how much influence the size of the company in moderating CAPEX to profit levels in telecommunications companies in Indonesia.

\section{Literature Review}

In allocating capital expenditure (CAPEX) in telecommunications companies, the aim is to improve the quality of company performance. For example, in capital expenditure, the addition of infrastructure and other supporting facilities will be able to expand the reach of communication services to consumers. With the addition of service facilities, one of the positive impacts that will be obtained is the increasing level of customer satisfaction, so that it will affect revenue, especially profitability.

\subsection{Capital Expenditure (CAPEX)}

Capital expenditure (CAPEX) is the costs incurred to obtain fixed assets, increase the output capacity of fixed assets, increase the level of efficiency of fixed assets, also extend the economic life of a fixed asset in the sense of economic benefits of more than one financial year. From the aspect of allocation, CAPEX can be divided into two parts, namely capex maintenance and growth capex. Maintanance capex is the capital spent to run the company's business using the amount of cash available. While the understanding of growth capex is capital spent with the aim of developing the company.

CAPEX is a number of funds spent by management for various needs such as property, plants, and equipment [7]. Meanwhile, capital expenditure is a company expenditure and defines it as an allocation of funds to be invested in various company assets [23]. In another study, it was stated that capital expenditure is an expenditure that can provide benefits in the future and therefore is treated as capital expenditure and not as a cost of the period when it occurs [8].

\subsection{Capital Expenditure in Telecommunication Sectors}

PT Telkom, Tbk, is a state-owned telecommunications company that sets a CAPEX target of $25 \%$ of the 2018 revenue target, which is expected to be sufficient to finance organic expansion such as building cable infrastructure [16]. PT Telkom, Tbk is also preparing expansion plans in the cellular and non-cellular lines to meet revenue targets. In 2017, PT Telkom, Tbk had 160,000 base transceiver stations (BTS) to support the cellular business that provides voice and SMS products. As many as 20,000 of them are 4G BTS. In 2018, PT Telkom, Tbk set capital expenditure to add 20,000 4G BTS. In the non-cellular business line, PT Telkom, Tbk includes IndiHome products. As of the third quarter of 2017, this triple play 
service recorded 30\% revenue growth (yoy). As of December 2017, the number of IndiHome customers was 2.96 million. And in 2018, PT Telkom, Tbk is targeting IndiHome customers to increase 1.5 million 1.7 million.

From the description above it can be seen that each telecommunications company emphasizes CAPEX for the benefit of the medium and long term. This will provide a very good impact for the company, especially in increasing revenue which will impact the profits to be gained. Following are the CAPEX data spent by 3 operator companies in Indonesia during the period 2009 to 2016.

Table 1. Capital Expenditure (CAPEX) of Telecommunication Sectors in Indonesia

\begin{tabular}{|c|r|r|r|}
\hline \multirow{2}{*}{ Year } & \multicolumn{3}{|c|}{ CAPITAL EXPENDITURE (in million rupiahs) } \\
\cline { 2 - 4 } & PT Indosat, Tbk & $\begin{array}{c}\text { PT Telkom, Tbk (including } \\
\text { PT Telkomsel) }\end{array}$ & PT XL Axiata, Tbk \\
\hline 2016 & 1.237 .831 & 4.132 .000 & 1.127 .000 \\
\hline 2015 & 1.236 .679 & 3.275 .000 & 1.433 .000 \\
\hline 2014 & 859.500 & 3.092 .000 & 1.424 .000 \\
\hline 2013 & 893.600 & 3.044 .000 & 1.355 .000 \\
\hline 2012 & 920.300 & 3.094 .000 & 1.306 .000 \\
\hline 2011 & 855.700 & 3.278 .000 & 1.238 .000 \\
\hline 2010 & 986.000 & 2.525 .000 & 1.291 .000 \\
\hline 2009 & 816.900 & 2.260 .000 & 1.260 .000 \\
\hline
\end{tabular}

\subsection{Profitability}

Current year's income is the company's income before deducting interest and tax expenses. Net income partially has the ability to predict future operating cash flows [31]. Profit is accounting profit which is the difference between measurement of income and costs [3].

Meanwhile, the definition of profit is the positive difference from income minus expenses. Income or income is funds that are channeled to businesses from the sale of goods or services, while expenses are costs incurred while producing goods or services. Measuring the rate of profit is done by comparing earnings with other measures. This study uses profit level analysis using Net Profit Margin (NPM) because it shows the effectiveness of selling prices and the efficiency of sales costs. NPM (Net Profit Margin) is formulated as follows [27]:

$$
\mathrm{NPM}=\frac{\mathrm{EAT} t}{\mathrm{NS} t}
$$

Remark:

$\mathrm{EATt}=$ Net income available for ordinary shareholders in $\mathrm{t}$ periods

$\mathrm{NSt}=$ Nett Sales in $\mathrm{t}$ periods 


\subsection{Firm's Size}

The size of the company has a different effect on the company's value of a company. In terms of company size seen from the total assets owned by the company, which can be used for company operations. If the company has a large total asset, management is more flexible in using the assets in the company. The freedom that this management has is proportional to the worries that the owner has over his assets. A large amount of assets will reduce the value of the company if judged from the owner of the company. However, if viewed from the management side, the ease it has in controlling the company will increase the company's value.

The size of the company can be interpreted as a measure of the size of the company seen from the value of equity, sales value, or the results of the total value of assets owned by the company. Company size is a picture of a company's financial capability in a certain period [12].

Small companies will tend to own capital costs and long-term debt costs more expensive than large companies. So small companies tend to prefer short-term debt than long-term debt because the cost is lower. Thus, large companies tend to have strong funding sources [12]. Size is a symbol of company size. The size of the company is represented by the Natural Log $(\mathrm{Ln})$ of total assets each year [9].

\section{Hypothesis Development}

\subsection{CAPEX has an influence on Profitability}

Expansion is undertaken to increase market share or improve quality to maintain market share, and related to these efforts the company must continue its efforts to meet the stockholder rate of return, a main indicator of which is level of profit [24]. The results of this study indicate that capital structure has no effect on the value of Indonesian BUMN companies in the 2015-2018 period, while capital expenditure and dividend policy have a positive effect on firm value and profitability has a negative effect on firm value [11]. This indicates the existence of investment opportunities that attract new investors so they will get high returns. In the research of NA Mutiara (2014) shows that capital expenditure was affects the profit rate. The other research shows that CAPEX and market share have a positive influence on profit [24].

$\beta_{1}=$ Is there the effect of CAPEX on Profitability?

\subsection{Firm Size has an influence on Profitability}

The effects of firm size on profitability of quoted manufacturing firms in Sri Lanka [20]. In this study, data of 15 companies which were active in Colombo Stock Exchange (CSE) between the years 2008 to 2012 has been used. There is no indicative relationship between firm size and profitability of listed manufacturing firms, the findings reveal.

The relationship between firm size and profitability has been studied in many different contexts; however, limited research is found in emerging countries. In this study, data from top 10 listed textile firms on Pakistan Stock Exchange from 2012 to 2016 was used. Net profit ratio and return on assets have been used as firm profitability while firm size has been determined through total sales and total assets. 
$\beta_{2}=$ Is there the effect of Firm Size on Profitability?

\subsection{CAPEX has an influence on Profitability that is Moderated by Firm Size.}

In the research that was conducted by Mahmood the result shows how the break-even point of the WCF-profitability relationship shifts when a company expands or its leverage level changes [15]. Estimation results suggest that after controlling for financial risk, liquidity level, growth opportunities, unsystematic risk, firm age, and the other factors, the indicators of firm size measured by firm's assets, sales and number of employees tend to have a positive influence on the profitability of firm measured by operating return on assets [17]. $\gamma=$ Is there the effect of CAPEX on Profitability that is moderated by Firm Size?

\section{Research Framework}

According to the hypothesis development, the following figure is the framework that will be used in this research.

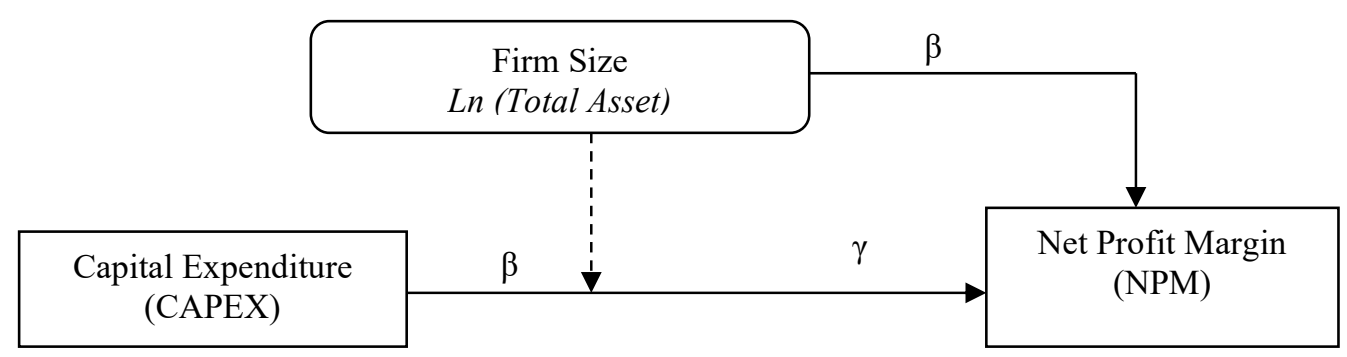

Fig.1. Research Framework

This research uses quantitative methods using financial statements obtained from the Indonesia Stock Exchange (IDX) database.

\subsection{Sample}

In this study samples were taken from telecommunications service companies listed on the Indonesia Stock Exchange (IDX). The data taken is an annual report from a telecommunications company accessed through www.idx.co.id. The researcher sets the sample for the object of research is the company with the following criteria:

a) Telecommunications service companies whose shares are listed on the Indonesia Stock Exchange in the 2009-2016 period.

b) Publish audited financial statements for at least 2009-2016.

\subsection{Hypothesis Testing Techniques}

a) Coefficient of Determination The coefficient of determination $\left(\mathrm{R}^{2}\right)$ essentially measures how far the model's ability to explain the variation of the dependent variable.

b) Simultaneous Significance Test (Statistical Test F) 
The F statistical test basically shows whether all independent variables or independent variables have a joint influence on the dependent variable / dependent variable. Thus, the hypothesis proposed by researchers is:

H0: CAPEX, the size of the company or Ln (total assets) and the moderate effect of the size of the company or Ln (total assets) simultaneously do not have a significant effect on the profitability of telecommunications companies listed on the Indonesia Stock Exchange in the 2009-2016 period.

Ha: CAPEX, the size of the company or Ln (total assets) and the moderate effect of the size of the company or Ln (total assets) simultaneously have a significant effect on the profitability of telecommunications companies listed on the Indonesia Stock Exchange in the 2009-2016 period.

$\mathrm{F}$ Test can be determined by using the following formula:

$$
F=\begin{array}{lr}
\left.\frac{R^{2} /(k-1)}{\left(1-R^{2}\right) /(n-k)} \quad \square 1\right),(n \square k) \square & \sim F \square(k \\
\square
\end{array}
$$

The following formula to find the $\mathrm{F}$ value of the table is as follows:

$$
\begin{array}{ll}
\mathrm{df} 1 & =(\mathrm{k}-1) \\
\mathrm{df} 2 & =(\mathrm{n}-\mathrm{k})
\end{array}
$$

Remark:

$$
\begin{array}{ll}
\mathrm{df} 1 & =\text { degree of freedom } 1 \\
\mathrm{df} 2 & =\text { degree of freedom } 2 \\
\mathrm{k} & =\text { number of variables } \\
\mathrm{n} & =\text { number of observations }
\end{array}
$$

So, in this study df $1=(4-1)=3$ and $\mathrm{df} 2=(30-4)=26$ with $\mathrm{F}$ values of tables 4,637 . To test this hypothesis F statistics with a significance level $(\alpha)$ used by researchers are 0.05 , the decision making criteria are as follows:

1) If $\mathrm{F}$ calculate $<\mathrm{F}$ table or probability value Sig. $>0.05$, then $\mathrm{H} 0$ is accepted, meaning that CAPEX and the moderate effect of company size or Ln (total assets) simultaneously do not have a significant effect on the level of profit of telecommunications companies listed on the Indonesia Stock Exchange in the 2009-2016 period.

2) If $F$ calculate $\geq F$ table or probability value $\mathrm{Sig}$. $\leq 0.05$, then $\mathrm{H} 0$ is rejected, meaning that CAPEX and the moderate effect of company size or Ln (total assets) simultaneously have a significant effect on the profit rate of telecommunications companies listed on the Indonesia Stock Exchange in the 2009-2016 period.

c) Significant Test of Individual Parameters ( $t$ Test)

To determine the effect of each independent variable on the dependent variable $Y$, the t-test was used [30]. In this study, using a two-way t test. Decision making is based on a comparison of the calculated t value of each regression coefficient with the value of $t$ table (critical value) in accordance with the level of significance used. The partial hypothesis is stated in the following form: 
1) There is an influence between CAPEX and the level of profit (NPM) of telecommunications companies listed on the Indonesia Stock Exchange in the 2009-2016 period.

2) There is an influence between the size of the company or Ln (total assets) and the profit rate (NPM) of telecommunications companies listed on the Indonesia Stock Exchange in the 2009-2016 period.

3) There is an influence between CAPEX which is moderated by the size of the company or Ln (total assets) to the level of profit (NPM) of telecommunications companies listed on the Indonesia Stock Exchange in the 2009-2016 period.

Decision criteria:

1) If $\mathrm{t}$ calculate $\geq \mathrm{t}$ table, or the probability value of $\mathrm{Sig}$. $\leq 0.05$, then $\mathrm{H} 0$ is rejected and $\mathrm{Ha}$ is accepted.

2) If $t$ calculate the $<\mathrm{t}$ table, or the probability value of Sig. $>0.05$, then $\mathrm{H} 0$ is accepted and $\mathrm{Ha}$ is rejected.

\section{Result And Discussion}

\subsection{Data Analysis Results}

In order to determine an appropriate model in determining the type of moderator variable is done by testing the coefficient of determination of two regression equations:

a) First Equation Results

Following is the regression equation for the first equation, which is the effect of CAPEX on the rate of profit.

$\mathrm{NPM}=\alpha+\beta 1 \mathrm{CAPEX}+\varepsilon$

Table 2. $R$ Square

\begin{tabular}{lllrr}
\hline Model & $\mathrm{R}$ & $\mathrm{R}$ Square & Adjusted R Square & \multicolumn{2}{c}{$\begin{array}{c}\text { Std. Error of the } \\
\text { Estimate }\end{array}$} \\
\hline 1 &, $773^{\mathrm{a}}$ &, 597 &, 579 &, 06676 \\
a. Predictors: (Constant), CAPEX & & \\
\hline
\end{tabular}

b) Second Equation Results

Following is the regression equation for the first equation, which is the effect of CAPEX on profit levels by adding firm size as a moderating variable.

$\mathrm{NPM}=\alpha+\beta 1 \mathrm{CAPEX}+\beta 2 \operatorname{Ln}($ Total Asset $)+\gamma$ CAPEX $^{*}$ Ln (Total Asset $)+\varepsilon$

Table 3. $R$ Square

\begin{tabular}{llllr}
\hline Model & $\mathrm{R}$ & R Square & Adjusted R Square & \multicolumn{2}{c}{$\begin{array}{c}\text { Std. Error of the } \\
\text { Estimate }\end{array}$} \\
\hline 1 &, $865^{\mathrm{a}}$ &, 748 &, 710 &, 05537 \\
a. Predictors: (Constant), CAPEX*LN(TA), CAPEX, LN (TOTAL ASET) &
\end{tabular}

c) t-Test Equation Results

Following are the results of data analysis that regresses between the CAPEX variable, and company size as a moderating variable on profit levels. 
Table 4. t-Test Results

\begin{tabular}{|c|c|c|c|c|c|}
\hline Model & $\begin{array}{c}\text { Sum of } \\
\text { Squares }\end{array}$ & $\mathrm{df}$ & Mean Square & $\mathrm{F}$ & Sig. \\
\hline Regression & ,182 & 3 &, 061 & 19,791 &, $000^{\mathrm{b}}$ \\
\hline Residual & 061 & 20 & 003 & & \\
\hline Total & 243 & 23 & & & \\
\hline
\end{tabular}

\subsection{Discussion}

According from table 2. it can be seen that the CAPEX variable influences the profit level variable by $59.70 \%$ ( $\mathrm{R}$ square value), which means that if the CAPEX spent increases by 1 unit of currency, the profit rate will be affected by $59.7 \%$. In line with research Riyanto (2010), that the addition of fixed assets aims to obtain the expected level of profit in the future. Meanwhile, fixed assets are often referred to as assets that actually generate income for the company because the fixed assets support the increase in corporate profits [28].

With the addition of the company size variable as a moderating variable, there is an increase in the effect of CAPEX on profitability. As in table 3 it is known that with the size of the company as a moderating variable, it actually strengthens the effect of CAPEX on the level of profit, amounting to $74.80 \%$ ( $\mathrm{R}$ square value). In table $4 \mathrm{t}$ test results indicate that partially, CAPEX has a positive and significant effect on earnings levels. Likewise, the company size variable which is proxied by Ln (Total Assets) has a positive and significant effect on profitability. This is indicated by the significance value of 0,000 .

\section{Conclussion}

According to the results of the analysis and discussion of the study, it can be concluded as follows:

a) There is a significant positive effect between capital expenditure (CAPEX) on the level of profit, with a level of influence of $59.70 \%$ (value $\mathrm{R}^{2}$ ). This means that the higher the CAPEX spent, the company's profit level will increase by $59.70 \%$.

b) There is a positive influence between the size of the firm on the level of profit, with a level of influence of $39.20 \%$ (value $\mathrm{R}^{2}$ ). This means that the higher the size of the firm obtained by the firm, the profit rate will increase by $39.20 \%$.

c) The firm size variable moderates between capital expenditure (CAPEX) and profit rate, with a level of influence of $74.80 \%\left(\mathrm{R}^{2}\right)$. Thus it can be concluded that the hypothesis is accepted, that the presence of moderating variables firm size reinforces or increases the effect of the CAPEX variable on profit levels.

In this study there are still limitations, namely the presence of other factors that influence the relationship between the CAPEX variable on the level of earnings. Besides the size of the company as a moderating variable. This can be seen from the amount of $\mathrm{R}$ square from the results of data analysis of each variable.

For future research, other variables can be added that will be additional variables, so that it will change the theoretical framework in research, and will have implications for readers who can use research as one of the sources of reference in determining company policy or in relation to further research. 


\section{References}

[1] Amato, Louis H., Burson, dan Thimothy E.: The Affect of Firm Size on Profit Rates in Financial Services. Journal of Economics and Economic Education Research, 8(1), 67-81. (2007).

[2] Brigham, dan Houston: Dasar-dasar Manajemen Keuangan. Penerbit Salemba Empat Edisi 11. (2010).

[3] Chariri, Anis, dan Imam Ghozali: Teori Akuntansi. Edisi Revisi. Semarang: Badan Penerbit UNDIP. (2001).

[4] Firli, Anisah: The Impact of Increasing CAPEX on Customer Number, Profit, and ROI in Indonesia Telecommunication Industry. American Journal of Economics, 5 (2), 135-138. (2015).

[5] Firli, Anisah: Tower Sharing Approach: Towards Sustainable Business Practices in Telecommunication Industry. Proceedings of GARCOMBS, International Conference. (2014).

[6] Fitri, Isa Nur: Jurnal Analisis Pengaruh Tingkat Kenaikan Penggunaan Capital Expenditure Terhadap Kinerja Perusahaan. Surabaya: Universitas Negeri Surabaya. (2013).

[7] Griner dan Gordon: Internal Cashflow, Insider Ownership and Capital Expenditure: A Test of The Pecking Order and Managerial Hypothesis. Journal of Business and Accounting. (1995).

[8] Horne, James C. Van dan John M. Wachowicz, Jr: Prinsip-prinsip Manajemen Keuangam $1^{\text {st }}$ Edition. Jakarta: Salemba Empat. (2009).

[9] Husnan, Saud: Dasar-dasar Teori Portofolio \& Analisis Sekuritas. Yogyakarta: UPP AMP YKPN. (1998).

[10] Indotelko.com: XL tantang Telkomsel di pasar luar Jawa. http: www.indotelko.com. diakses 26 April 2018.

[11] Işık, O.: Determinants of Profitability: Evidence from Real Sector Firms Listed in Borsa Istanbul. Business and Economics Research Journal, Vol. 8, NO. 10, pp. 689-698. (2017).

[12] Joni, \& Lina. (2010). Faktor-Faktor yang Mempengaruhi Strukrut Modal. Jurnal Bisnis dan Akuntansi Vol. 12 No. 2, 81-96.

[13] Khan \& Jain: Financial Management. Mc Graw Hill. (2007).

[14] Kontan.co.id: Indosat pakai dana obligasi untuk belanja modal 2018. https: investasi.kontan.co.id. diakses 26 April 2018.

[15] Mahmood, Faisal, et.al: Moderating Effects of Firm Size and Leverage on the Working Capital Finance-Profitability Relationship: Evidence from China. Sustainability Journal. 11, 2029. (2019).

[16] Market.bisnis.com: Telkom (TLKM) Targetkan Pertumbuhan Pendapatan 2018 Tembus Dua Digit. http: market.bisnis.com. diakses 26 April 2018.

[17] Mispiyanti: Pengaruh Struktur Modal, Capital Expenditure, Profitabilitas Dan Kebijakan Dividen Terhadap Nilai Perusahaan Pada Perusahaan BUMN Indonesia. Jurnal Akuntansi dan Pajak, 20(2), 2020, 133-144. (2020).

[18] Munawir, Slamet: Analisis Laporan Keuangan. Yogyakarta: Liberty. (2004).

[19] NA. Mutiara, and Kartawinata, BR: Pengaruh Capital Expenditure Terhadap Tingkat Laba Dengan Kinerja Perusahaan Sebagai Variabel Moderator (Pada Perusahaan Jasa Telekomunikasi yang Terdaftar di Bursa Efek Indonesia Periode 2009-2013). Jurnal Fakultas Komunikasi dan Bisnis Universitas Telkom. (2015)

[20] Niresh, j. ALoy, and Velnampy, T.: Firm Size and Profitability: A Study of Listed Manufacturing Firms in Sri Lanka. International Journal of Business and Management; Vol. 9. No. 4. (2014).

[21] Ozcan Isik, Esra Aydin Unal, Yener Unal: The Effect of Firm Size on Profitability: Evidence From Turkish Manufacturing Sector. Business, Economics and Finance Journal (JBEF). (2017).

[22] Pwc.com: Telecom Capital Expenditure. https: www.pwc.com. diakses 26 April 2018.

[23] Riyanto, Bambang: Dasar-dasar Pembelanjaan Perusahaan. Yogyakarta: Yayasan Badan 
Penerbit UGM. (2001).

[24] Rosandy, Nursakti Niko dan Mita, Aria Farah: The Effect of Capital Expenditure and Market Share on Profits per Region in an Indonesian Mobile Telecommunications Company. Advances in Economics, Business and Management Research (AEBMR), volume 55 6th International Accounting Conference. (2017).

[25] Saphiro, Alan: Capital Budgeting and Investment Analisys. First Edition. New York: Pearson/Prentice Hall. (2004).

[26] Sudiyatno, Bambang, and Puspitasari, Elen: Perusahaan Tobin's Q and Altman Z-Score as Indicators of Performance Measurement Company. Kajian Akuntansi, pp. 9 - 21 Vol. 2. No. 1. (2010).

[27] Sugiono: Manajemen Keuangan untuk Praktisi Keuangan. Jakarta: Grasindo. (2009).

[28] Syamsuddin, Lukman: Manajemen Keuangan Perusahaan: Konsep Aplikasi dalam Perencanaan, Pengawasan, dan Pengambilan Keputusan. Jakarta: Rajawali Pers. (2009).

[29] The Economist Intelligence Unit: Telecoms in 2018: A special report from The Economist Intelligence Unit. (2017).

[30] Ghozali, Imam: Aplikasi Analisis Multivariate Dengan Program SPSS. Semarang: Badan Penerbit Universitas Diponegoro. (2011).

[31] Yuwana, V., Jogi,Y: Analisis Kemampuan Laba dan Arus Kas Operasi dalam Memprediksi Arus Kas Operasi Masa Depan. Jurnal Business Accounting Review, Volume. 2, No, 1. (2014).

[32] V. Wiratna S.: Penelitian Akuntansi dengan SPSS. Penerbit Pustaka Baru Press. Yogyakarta. (2016). 